\title{
HUBUNGAN INISIASI MENYUSU DINI (IMD) DAN PEMBERIAN AIR SUSU IBU (ASI) EKSKLUSIF DI RSUD WANGAYA KOTA DENPASAR
}

\author{
Jessica Irawan \\ SMF Anak RSUD Wangaya Denpasar \\ jessica_irawan@hotmail.com
}

\begin{abstract}
Immediate breastfeeding indeed has positive impacts for both mother and baby. Based on Fika's and Syafiq's research, a mother who does immediate breastfeeding has 2-8x higher chance in giving exclusive breastfeeding. The purpose of this research is to understand the relationship between immediate breastfeeding and exclusive breastfeeding at Kaswari Ward Wangaya Hospital, Denpasar City. For this research, we used analytic approach with case control as the study design. Population that we use was mothers who have 7-12 months old baby in Kaswari Ward Wangaya Hospital, Denpasar City. Sampling was done through purposive sampling method, with the sample of 50 mothers. Whereas, data analysis was done by using chi square method. The result of this research shows that there was positive correlation between the practice of immediate breastfeeding and giving exclusive breastfeeding ( $p$ value=0,04). Thus, mother who practices immediate breastfeeding has $5 x$ higher opportunity to give exclusive breastfeeding.
\end{abstract}

Keywords: Immidiate Breastfeeding, Exclusive Breastfeeding, The mothers Group Who Gets Health Services at Wangaya Hospital

\begin{abstract}
Abstrak. Menyusui sejak dini mempunyai dampak yang positif baik bagi ibu maupun bayinya. Menurut hasil penelitian Fika dan Syafiq, Ibu yang melakukan IMD 2 sampai 8 kali lebih besar kemungkinannya untuk memberikan ASI secara eksklusif. Tujuan penelitian ini untuk mengetahui hubungan IMD dengan pemberian ASI eksklusif di Ruang Kaswari RSUD Wangaya Kota Denpasar. Jenis penelitian yang digunakan adalalah penelitian analitik dengan desain studi case control. Populasi pada penelitian ini adalalah ibu yang memiliki bayi usia 7 - 12 bulan di Ruang Kaswari RSUD Wangaya Kota Denpasar. Pengambilan sampel dilakukan dengan cara purposive sampling dengan jumlah sampel $50 \mathrm{ibu}$. Analisa data dilakukan dengan menggunakan chi square. Hasil penelitian ini menunjukan pelaksanaan IMD mempunyai hubungan yang signifikan dengan pemberian ASI eksklusif ( $p$ value $=0,04$ ), ibu yang melaksanakan IMD memiliki peluang 5 kali lebih besar untuk memberikan ASI eksklusif.
\end{abstract}

Kata kunci: IMD, ASI Eksklusif, kelompok ibu yang mendapat pelayanan kesehatan di RSUD Wangaya 


\section{Pendahuluan}

Diperkirakan 4 juta bayi baru lahir meninggal setiap tahunnya. ${ }^{1}$ Pada data yang telah dirilis oleh UNICEF tahun 2010, di Indonesia tercatat angka kematian bayi masih sangat tinggi yaitu $2 \%$ dari kematian bayi di seluruh dunia dan jumlah bayi yang meninggal adalah 17 tiap 1000 kelahiran hidup. Hasil penelitian menunjukkan bahwa Inisiasi Menyusu Dini (IMD) dapat menyelamatkan 22\% dari bayi yang meninggal sebelum usia 1 bulan. ${ }^{2}$ Berdasarkan Peraturan Pemerintah Nomor 33 Tahun 2012, pengertian ASI eksklusif adalah ASI yang diberikan kepada bayi sejak dilahirkan sampai usia 6 bulan tanpa menambahkan dan mengganti dengan makanan atau minuman lain, kecuali suplemen vitamin, obat, dan mineral. Manfaat ASI akan meningkat jika bayi hanya diberi ASI saja selama enam bulan pertama kehidupannya. ${ }^{1,2}$ ASI Eksklusif memiliki kontribusi yang besar terhadap tumbuh kembang dan daya tahan tubuh anak. Anak yang diberi ASI Eksklusif akan tumbuh dan berkembang secara optimal dan tidak mudah sakit. Hal tersebut sesuai dengan beberapa kajian dan fakta global.

Kajian global The Lancet Breastfeeding Series, 2016 telah membuktikan: 1) Menyusui Eksklusif menurunkan angka kematian karena infeksi sebanyak $88 \%$ pada bayi berusia kurang dari 3 bulan; 2) Sebanyak 31,36\% (82\%) dari 37,94\% anak sakit, karena tidak menerima ASI Ekslusif. Investasi dalam pencegahan BBLR, Stunting dan meningkatkan IMD dan ASI Eksklusif berkontribusi dalam menurunkan risiko obese dan penyakit kronis. Tidak menyusui berhubungan dengan kehilangan nilai ekonomi sekitar \$302 milyar setiap tahunnya atau sebesar $0-49 \%$ dari Pendapatan Nasional Bruto. ${ }^{3}$

Menurut hasil penelitian Fika dan Syafiq, ${ }^{4}$ ibu yang memberikan immediate breastfeeding 2 sampai 8 kali lebih besar kemungkinannya untuk memberikan ASI secara eksklusif dibandingkan dengan ibu yang tidak immediate breastfeeding. Menurut hasil penelitian Rahayu, dkk. ${ }^{5}$ menunjukkan bahwa ada perbedaan bermakna antara keberhasilan IMD terhadap lama pemberian ASI. Menurut penelitian $^{4,5}$, ibu yang melakukan IMD akan akan berhasil memberikan ASI eksklusif kepada bayi mereka. Namun, pada kenyataannya masih ada ibu yang gagal memberikan ASI eksklusif walaupun telah melakukan IMD. Mengacu pada temuan-temuan mengenai hubungan antara ASI eksklusif dan IMD merupakan alasan peneliti untuk melakukan penelitian ini. 
Metode

Penelitian ini menggunakan metode penelitian analitik dengan desain studi case control. Penelitian case control adalah suatu penelitian analitik yang menyangkut bagaimana faktor resiko dipelajari dengan menggunakan pendekatan retrospective, perbandingan kasus dan kontrol adalah 1 : 1 . Waktu penelitian dilaksanakan pada bulan Juli September 2017. Populasi penelitian ini seluruh pasien anak usia 7-12 bulan yang dirawat di Ruang Kaswari RSUD Wangaya Denpasar. Jumlah sampel 50 orang dibagi menjadi 25 sampel kontrol dan 25 sampel kasus, dengan teknik sampling judgemental sampling atau purposive sampling.

Peneliti memilih responden berdasarkan kemampuan responden untuk memberikan informasi yang memadai untuk menjawab pertanyaan penelitian dengan memperhatikan kriteria inklusi dan eksklusi, dengan kriteria inklusi ibu yang mempunyai bayi usia 7-12 bulan dirawat di Ruang Kaswari RSUD Wangaya Kota Denpasar dan bersedia mengikuti penelitian setelah mendapatkan penjelasan (PSP). Sedangkan kriteria eksklusi adalah pasangan ibu dan bayi mengalami sakit berat dan Ibu yang lupa masalah IMD. Hubungan antara inisiasi menyusui dini (IMD) dan pemberian ASI eksklusif menggunakan uji hipotesis $\chi^{2}$. Batas kemaknaan adalah apabila $\mathrm{p} \leq 0.05$ dengan interval kepercayaan 95\%. Analisis data dilakukan dengan program SPSS (Statistical Product and Service Solution).

\section{Hasil Penelitian dan Pembahasan}

Karakteristik subjek penelitian

Tabel 1

Karakteristik Sampel Penelitian

\begin{tabular}{cllll}
\hline No & \multicolumn{1}{c}{ Karakteristik } & \multicolumn{1}{c}{ Kategori } & \multicolumn{1}{c}{$\begin{array}{c}\text { Kasus }(\%) \\
(\mathrm{n}=25)\end{array}$} & $\begin{array}{c}\text { Kontrol }(\%) \\
(\mathrm{n}=25)\end{array}$ \\
\hline 1. & Umur Ibu & Mean \pm SD & $28 \pm 5,3$ & \\
& & $\leq 20$ & $1(4 \%)$ & $1(4 \%)$ \\
& & $21-35$ & $23(92 \%)$ & $20(80 \%)$ \\
& & $>35$ & $1(4 \%)$ & $4(16 \%)$ \\
\hline 2. & Paritas & Primipara & $11(44 \%)$ & $7(28 \%)$ \\
& & Multipara & $14(56 \%)$ & $18(72 \%)$ \\
3. & Pendidikan & SD & $0(0 \%)$ & $1(4 \%)$ \\
& & SMP & $5(20 \%)$ & $4(16 \%)$ \\
& & SMA & $17(68 \%)$ & $19(76 \%)$ \\
& & Diploma & $2(8 \%)$ & $1(4 \%)$ \\
4. & Pekerjaan & Sarjana & $1(4 \%)$ & $0(0 \%)$ \\
\hline & & Tidak bekerja & $20(80 \%)$ & $17(68 \%)$ \\
& & Bekerja & $5(20 \%)$ & $8(32 \%)$ \\
\hline
\end{tabular}




\begin{tabular}{llll}
\hline 5. Pendapatan Keluarga & $\begin{array}{l}\text { Dibawah UMR } \\
\text { Diatas UMR }\end{array}$ & $15(60 \%)$ & $18(72 \%)$ \\
& & $7(28 \%)$ \\
\hline
\end{tabular}

Karakteristik umur ibu yang memiliki bayi usia 7 - 12 bulan di Ruang Kaswari RSUD Wangaya Kota Denpasar tahun 2017 dibagi dalam 3 kelompok umur, dengan nilai minimal 17 tahun, maksimal 39 tahun, rerata 28 tahun, median 28 tahun, modus 29 tahun, standart deviasi $\pm 5,383$ tahun, data berdistribusi normal. Berdasarkan tabel dan gambar di atas menunjukkan bahwa $86,0 \%$ ibu yang memiliki bayi usia $7-12$ bulan berusia 21 hingga 35 tahun. Usia $\leq 20$ tahun dianggap usia yang berisiko untuk kehamilan, selain itu secara mental dan psikologis dianggap masih belum cukup matang dan dewasa untuk menghadapi kehamilan dan kelahiran. Usia 21 - 35 tahun adalah kelompok umur yang paling baik untuk kehamilan baik secara fisik maupun mental. Usia > 35 tahun dianggap berisiko untuk kehamilan, sebab kesehatan reproduksi mulai menurun. ${ }^{6}$

Sebesar 64\% ibu multipara, Adanya kaitan antara paritas dengan pemberian ASI eksklusif menunjukan pengalaman ibu menyusui berperan dalam tindakannya memberikan ASI eksklusif. Hal ini sejalan dengan teori Notoatmojo ${ }^{7}$, bahwa pengaruh pengalaman sendiri maupun orang lain terhadap pengetahuan dapat mempengaruhi perilaku saat ini atau kemudian. berpendidikan SMA, banyaknya $72 \%$. Jika dilihat dari tingkat pendidikan, pendidikan SMA bukan termasuk kategori pendidikan yang rendah, tetapi menengah. Seorang ibu yang berpendidikan tinggi belum tentu memiliki perilaku pemberian ASI eksklusif. Semakin tinggi tingkat pendidikan ibu biasanya mempunyai banyak kesibukan di luar rumah seperti bekerja, sedangkan ibu berpendidikan rendah lebih banyak tinggal di rumah hingga memiliki kesempatan lebih banyak untuk menyusui bayinya.

Sebanyak $74 \%$ responden tidak bekerja.Ibu yang tidak bekerja memiliki kesempatan lebih banyak untuk memberikan ASI eksklusif, namun pada penelitian ini presentase pemberian ASI eksklusif lebih rendah $(50,0 \%)$ dibandingkan presentase ibu yang tidak bekerja. Pekerjaan ibu dapat mempengaruhi kesempatan dan pengetahuan ibu tentang ASI eksklusif, ibu yang bekerja di luar rumah memiliki akses yang lebih baik terhadap berbagai informasi, termasuk mendapatkan informasi tentang pemberian ASI eksklusif.

Karakteristik demografi pendapatan keluarga dibagi menjadi 2, di bawah UMR dan di atas UMR, dimana UMR kota Denpasar pada tahun 2017 sebesar Rp 
2.500.000,00. Tabel di atas menunjukan 66.0\% keluarga berpendapatan di bawah UMR. Menurut Suradi dan Roesli ${ }^{8}$, pemberian ASI eksklusif dapat meringankan ekonomi keluarga. Hal ini dikarenakan ibu yang memberikan ASI eksklusif tidak perlu membeli susu formula, selain itu dengan memberikan ASI eksklusif bayi akan lebih sehat sehingga mengurangi biaya pengobatan.

Tabel 2

Pengaruh IMD terhadap ASI eksklusif

\begin{tabular}{lccccc}
\hline Variabel & \multicolumn{2}{c}{ ASI Eksklusif } & Total & RO (IK 95\%) & p Value \\
\cline { 2 - 3 } & Ya & Tidak & & & \\
IMD & 16 & 6 & 22 & 5,63 & 0,04 \\
Ya & 9 & 19 & 28 & $(1,64-19,23)$ & \\
Tidak & 25 & 25 & 50 & & \\
\hline Total & & & & &
\end{tabular}

Dari hasil penelitian ini didapatkan jumlah sampel yang mendapatkan IMD adalah sebesar 22 sampel (44\%) dan sisanya sebanyak 28 sampel $(66 \%)$ tidak mendapatkan IMD. Tabel 2 memperlihatkan hasil uji hipotesis dengan menggunakan uji chi square, dimana didapatkan nilai $\mathrm{p}$ sebesar 0,04. Karena nilai $\mathrm{p}<0,05$, maka dapat disimpulkan bahwa pelaksanaan IMD mempunyai hubungan dengan pemberian ASI eksklusif.

Untuk mengetahui besarnya hubungan tersebut, dilakukan perhitungan Rasio Odds (RO). Berdasarkan Tabel 5.2, maka nilai OR adalah 5,63 dengan IK 95\% 1,64-19,23 yang berarti OR terletak antara 1,64-19,23. Pada interpretasi hasil OR menunjukan hubungan yang kuat, sehingga pada penelitian ini menunjukkan ASI eksklusif memiliki hubungan yang kuat dengan pelaksanaan IMD $(\mathrm{OR}=5,63)$. Ibu yang melaksanakan IMD memiliki peluang 5 kali lebih banyak untuk memberikan ASI ekslusif daripada ibu yang tidak melaksankan IMD.

Ketika bayi diletakkan di dada untuk menyusu, bayi akan merasakan kehangatan dari kulit ibu sehingga dapat menurunkan risiko kematian karena hipotermia. Selama menyusu, bayi akan mengkoordinasikan isapan, menelan dan bernapas. Pada saat itu, mungkin ibu sudah mengeluarkan kolostrum. Bayi yang mendapatkan kolostrum akan mendapatkan antibodi dan faktor pertumbuhan sel usus, antibodi dalam ASI dapat meningkatkan ketahanan terhdap infeksi. Berbagai literatur menyebutkan bahwa segera setelah bayi lahir harus 
diletakkan di dada ibu dengan cara menempelkan bayi pada payudara ibu, dalam hal ini bukan untuk pemberian nutrisi tetapi agar bayi dapat belajar untuk menyusu dan mengenal puting ibu, selain itu rangsangan hisapan dari bayi akan merangsang kelenjar hipofisis posterior mengeluarkan hormon oksitosin untuk mempercepat pengeluaran ASI. Walaupun ASI belum keluar, tetapi interaksi ini akan membuat bayi merasa tenang dan nyaman, selain itu hormon oksitosin dapat mengurangi perdarahan pasca persalinan dan mempercepat pengecilan uterus.

Kelemahan pada penelitian jenis ini rentan terjadi bias waktu dan informasi. Pengumpulan data menggunakan kuesioner yang sifatnya subyektif, sehingga kebenaran data sangat tergantung pada kejujuran dan daya ingat responden serta kejujuran dan kepekaan dari pewawancara (observer) pada saat observasi dan pengisian kuesioner yang tentunya akan sangat mempengaruhi terhadap data dan informasi yang dihasilkan. Selain itu peneliti tidak meneliti apakah tehnik menyusu ibu sudah benar atau belum, bayi disusui langsung atau menggunakan dot, hal ini menjadi penting karena tehnik menyusui mempengaruhi pengeluaran ASI.Peneliti juga tidak meneliti peran keluarga dalam keberhasilan pemberian ASI eksklusif, hal ini menjadi penting karena keluarga dapat memberikan dorongan kepada ibu untuk memberikan ASI eksklusif.

\section{Simpulan dan Saran}

Berdasarkan penelitian yang telah dilakukan dapat disimpulkan bahwa : 1) Menyusu sejak dini berhubungan dengan keberhasilan pemberian ASI eksklusif $(\mathrm{p}=$ 0,04), hisapan dari bayi akan mempengaruhi pengeluaran hormon oksitosin dan prolaktin, selain itu bayi juga belajar untuk menyusu, sehingga terdapat kemungkinan menyusui sejak dini berpengaruh terhadap produksi dan pengeluaran ASI. 2) Faktor yang mungkin berpengaruh terhadap pemberian ASI eksklusif adalah karakteristik demografi ibu, yaitu umur, paritas, pendidikan, status pekerjaan, dan pendapatan keluarga. 3) Tiap responden memiliki karakter yang berbeda dengan responden yang lain sehingga kemungkinan keberhasilan pemberian ASI eksklusif dipengaruhi oleh tiap karakter responden. 4) Ibu yang melakukan IMD memiliki peluang 5 kali lebih besar untuk memberikan ASI eksklusif daripada ibu yang tidak melakukan IMD, peluang 5 kali didapatkan dari nilai OR yang berarti memiliki hubungan yang kuat.

Dengan adanya kekurangan dan kelemahan dari penelitian ini, penulis 
memberi saran agar bagi penelitian selanjutnya dapat melakukan penelitian lebih lanjut mengenai faktor - faktor kegagalan pemberian ASI eksklusif pada ibu yang telah melakukan IMD, selain itu dapat menyertakan peran keluarga, teknik menyusui, dan cara pemberian ASI (menggunakan dot atau langsung) dalam faktor - faktor yang mempengaruhi pemberian ASI eksklusif. Bagi instansi kesehatan diharapkan dapat memberikan informasi mengenai hubungan IMD terhadap keberhasilan pemberian ASI eksklusif kepada ibu yang sedang hamil dan memberikan dorongan untuk melakukan IMD, selain itu tiap instansi kesehatan diharapkan dapat memberikan informasi dan dorongan kepada ibu menyusui untuk memberikan ASI eksklusif.

\section{Daftar Pustaka}

1. Yohmi E. Inisiasi Menyusu Dini. Dalam Raulina Suradi, Badriul Hegar, I.G.A.N. Partiwi, A.N. Sacharina Marzuki, Y.Ananta (Ed.). Indonesia Menyusui. Jakarta: Badan Penerbit IDAI; 2010.

2. Edmond KM, Zandoh C, Quigley MA, Amenga etego S, Owusu-Agyei S and Kirkwood BR. Delayed breastfeeding initiation increases risk of neonatal mortality. Pediatrics; 2006. Diunduh dari: http://www.pediatrics.org/cgi/ content/full/117/3/e380.
3. Kementrian Kesehatan RI. Pedoman PAS 2016 KEMENKES Direktorat Gizi Masyarakat; 2016. Diunduh dari: www.diskes.baliprov.go.id/files/.../diskes/ Agustus\% 202016/Pedoman PAS 2016. pdf

4. Fikawati S, Syafiq A. Kajian Implementasi dan KebijakanAir Susu Ibu Eksklusif dan Inisiasi Menyusu Dini di Indonesia. Kesehatan Vol. 14, No. 1; 2010.

5. Rahayu RD, Kuswati, Kurniawati A. Keberhasilan Inisiasi Menyusu Dini (IMD) dan Lama Pemberian ASI. Jurnal Terpadu Ilmu Kesehatan Jilid 1; 2012.

6. Depkes RI. Indonesia Sehat 2010 Visi, Misi, Kebijakan Strategi Pembangunan Kesehatan. Jakarta: Depkes RI; 1999

7. Notoatmodjo S. Pendidikan dan Perilaku Kesehatan.Jakarta: Rineka Cipta; 2003.

8. Suradi R, Roesli U. Manfaat ASI dan Menyusui. Jakarta: Balai Penerbit FKUI; 2008. 